\title{
REGINA KREIDE \\ The Ambivalence of Juridification. On Legitimate Governance in the International Context ${ }^{1}$
}

\begin{abstract}
The paper argues that the current global market is organized by a system of transnational law whose development is best characterized as ambivalent. On the one side, legal juridification can lead to a hegemonic system of international law that lacks legitimacy, paradoxically creates extralegal spheres, promotes the 'privatization' of political areas, and, thereby, reduces the competences of states. On the other side, legal codification can also function as an engine of transnational democratization and as a barrier to an unhampered growth of transnational administrative and executive power.

Scholarship on the idea of legitimacy in law and transnational governance in political and legal theory has to reflect these aspects of juridification on a world scale. Most approaches to the issue, however, have serious flaws: they neither offer an adequate empirical diagnosis of the de-embedding of international economic and legal processes, nor do they provide convincing proposals as to how such processes could be domesticated.
\end{abstract}

Against this background, the paper lays out a critical analysis of legal codification processes as well as proposing an account of democratic governance, based on a realistic conception of deliberative democracy.

KEY WORDS: democratic governance, deliberative democracy, public sphere, international relations.

Among the complex processes that fall under the globalization label there are above all two dynamics that have fundamentally transformed the international structural order. By means of a progressive socialization of international relations states have handed over formidable authority for decision and organization to other international actors (NGO's, international economic and financial organizations, private corporations). In the passage from the national to the 'post-national constellation' non-state actors undertake what were previously governmental tasks, for instance energy supply, security issues, WTO negotiations, or regulations for environmental protection and human rights. ${ }^{2}$

At the same time, a strengthened juridification of international relations has led to the fact that communication between new and old actors is no longer

1. Many thanks to Ayelet Banai, Miriam Ronzoni, and Christian Schemmel for her very helpful comments and suggestions.

2. Perraton, J./Goldblatt, D./Held, D.,/McGrew, A., "Die Globalisierung der Wirtschaft“ in: Beck, Ulrich (ed.), Politik der Globalisierung (Frankfurt/M: Suhrkamp 1998), 134-169; Habermas, Jürgen, Between Facts and Norms (Cambridge (MA): MIT Press, 1996); recently, Leibfried, Stephan/Zürn, Michael, Transformations of the State?, Cambridge (UK): Cambridge University Press, 2006). 


\section{THE AMBIVALENCE OF JURIDIFICATION. ON LEGITIMATE GOVERNANCE IN THE INTERNATIONAL CONTEXT}

primarily characterized by informal, diplomatic relations, but proceeds along legally formalized tracks. These can be understood as an expansion in terms of content and as a proceduralization of infrastructure according to international law. Procedural regulations can be found not only for the security domain, but also for the economic, cultural and social domains. ${ }^{3}$ Both processes decisively shape governance beyond the nation state and contribute significantly to the development of transnational governing institutions. Following Renate Mayntz's definition, I characterize governing institutions as the collective, non-hierarchical regulations for societal states of affairs that serve to establish a political order. ${ }^{4}$

Virtually impossible to overlook, however, are the 'dysfunctionalities' that emerge as a consequence of juridification and that have far-reaching negative effects on the socialization of the citizens. They range from the generation of hegemonic, democratically deficient legislation, to its deformalization and a lack of separation of powers in a multi-leveled system, to the disempowerment of politics and the exclusion of a great part of the global population from access to money, knowledge, power, and judicial outlets for grievances.

Thelong-neglectedandextremelycontroversialquestion regardingthelegitimacy of transnational governing institutions emerges more pressing than ever. What normative demands must transnational governance comply with? And when is transnational law legitimate? Many theorists agrees that the normative demands, as we understand them to be self-evident for the democratic nation state, are too optimistic. The democratic participation of citizens in transnational negotiations and other law-making forums, and also the need to limit administrative and executive power, are considered to be either completely utopian or normatively undesirable. ${ }^{5}$ On the other hand, the problems that originate with the nonhierarchical coordination of function-specific domains are not banal and make a watering down of legitimizing needs appear quite questionable.

In what follows I shall propose a conception of legitimacy for transnational governance that must be measured against the problems appearing in the course of juridification-problems that are still to be sketched out. The conception of 'democratic governance' advocated here against skeptics connects deliberation with democratic elements and public spheres with an institutionalized praxis of justification. This happens in a way that saves the project from falling prey to the 'powerlessness of the ought'; but endows it with normative and empirical advantages over other formulations. The legitimacy of democratic governance thereby arises from a coupling of deliberation and democratic elements. Naturally,

3. Abbott, Kenneth W./Keohane, Robert O./Moravcsik, Andrew/Slaughter, Anne-Marie/Snidal, Duncan "The Concept of Legalization", in: International Organization, 54 (2000), 401-419.

4. Mayntz, Renate, "Governance im modernen Staat", in: Benz, Arthur (ed.), Governance - Regieren in komplexen Regelsystemen (Wiesbaden: VS Verlag für Sozialwissenschaften, 2004), 65-76.

5. Moravcsik, Andrew, “Is There a Democratic Deficit in World Politics?”, in: Government and Opposition, 39 (2004), 336-363, among others, is skeptical regarding democratic forms of transnational government. He measures the EU against 'real world standards' and thus can discern no democracy deficit. Outside of the EU region he barely sees any possibilities for the realization of transnational democracy. Allen Buchanan and Robert O. Keohane are also sceptical (Buchanan, Allen/Keohane, Robert O., "The Legitimacy of Global Governance", Ethics and International Affairs 20 (2006), 4-37. They invoke missing social and political conditions. 
what is being offered here is not only a description of existing relations, but also an argument in favor of an ideal that already looms in an institutional context; and the argument develops incentives for the further realization of this ideal.

Firstly, I will present which developments of a global society have been considerably transformed by transnational rule-setting and implementation, and which legitimacy deficits have arisen thereby. They concern democratic lawmaking under conditions of a plural system of law, the dialectic of juridification and de-juridification, and the de-politicization of international relations (1). Secondly, I shall advocate a conception of legitimacy against critics, characterized by three features: it is based on decentrally organized forums of deliberation, on democratic equivalents of transnational governance and on public spheres, which have the potential for a critique of the negative consequences of functional juridification in the global society. This shows that the conception developed here does not remain in the cocoon of a mere normative demand (2). I conclude that the implementation of these forms of transnational governance is already supported by an institutionalized praxis of reciprocal justification.

\section{Problems of Juridification}

Juridification processes are ambivalent. On the one hand, they can be understood as an indication of a formal shifting of sovereignty to a supranational plane. Seen from this perspective, they could pave the way for a legitimate and efficient form of 'global governance', that is, for a structure of governance that goes beyond the nation state and aims at the formation of transnational systems of law, to the point of reaching a global constitution. On the other hand, processes of juridification produce anomic internal and transnational conditions. I will discuss the three most important ones: 1. the fragmentation of a unitary law into plural systems of law and the associated de-democratization ; 2. the dialectic between juridification and de-juridification; 3. the de-politicization of international relations. All of these specify the conditions that a critical confrontation with the demands of legitimacy directed at transnational governance must consider. They pose the question how the gaps in legitimacy caused by the shifting of what previously were nation state government tasks towards international organizations and networks could be mended.

\subsection{De-democratization}

The international system of law, based on the inner-societal functional differentiation, has long ago already become pluralized concerning domains, ${ }^{6}$ which has led to the development of hegemonic international structures of law. This seems to be a paradoxical assertion, for one could think that a functional pluralization of law displaces the existent constellations of power in favor of previously less powerful actors. However, this is not the case at all. Rather a development, labeled here 'de-democratization', is portrayed. This does not mean that there were peculiar forms of transnational democratization before, which now disappear. De-democratization refers to the fact that, with the fragmentation

6. Koskenniemi, Martti, The Gentle Civilizer of Nations (Cambridge (UK): Cambridge University Press, 2004). 


\section{THE AMBIVALENCE OF JURIDIFICATION. ON LEGITIMATE GOVERNANCE IN THE INTERNATIONAL CONTEXT}

of unitary law, the realization of transnational democratization and possible strengthening of earlier already powerless actors is thwarted. I would like to clarify this by explaining three aspects of this process.

Inequality. As soon as in addition to a central law-giver there are further legislating bodies that operate in different transnational domains of law, and on different local, regional, national, international and transnational planes, the one system of law disintegrates into a myriad of systems of norms. With it, the structure of a hierarchically gradated order of primary and secondary norms that possess their unifying basis in a fundamental norm disintegrates. ${ }^{7}$ The fact of the pluralism of law, following Klaus Günther, upsets the familiar principle of equal treatment for equal cases, since it undermines the possibility of relating to one sole system of norms equally valid for all legal entities. In this way it opens up maximum maneuvering room for a legal interpretation that relies on power.

Incongruence between the authors of law and its subjects. In addition, it is considered a historical accomplishment that in the production of primary and secondary norms or in the practice concerning norms within a democratic constitutional state, there is no domain deprived of the citizens' norm-giving activities. However, this is precisely presently the case on the transnational plane. Whereas in the democratic constitutional state political autonomy ensured societal inclusion side by side with the protection of private autonomy, the congruence between authors of the law and its subjects is dissolved through the plurality of systems of law. And whereas international organizations, such as the World Trade Organization (WTO), the World Bank, the International Monetary Fund (IMF), and even the EU by representing the interests of their member states represent at least indirectly the will of their citizens, this does not apply to non-state actors such as transnational corporations and non-governmental organizations (NGO's). International law-for example the Lex mercatoria-appears as hegemonic law, that is, as law that lays hands on nation state matters without adequate and direct representation of all interests involved.

Confrontation between law-making and law-enforcement. Finally, lawmaking and law-enforcement have already come asunder in the international accrual of rights. This can be seen particularly clearly in United Nations law and also at the EU level, for instance, in the direct effects of European law on the law of the individual member states. A particularly clear example of this is the priority of European over national law in cases of conflict. ${ }^{8}$ Here, there obviously exists a gulf between law-enforcement of substantial norms and a procedural juridification only slowly catching up, which cannot be bridged without the will of the politically powerful international actors.

\subsection{De-Juridification}

Juridification admittedly possesses still more negative 'implications'. Some voices warn that a stronger 'privatization' of international relations could

7. Günther, Klaus, "Rechtspluralismus und universaler Code der Legalität“, in: Günther, Klaus/Wingert, Lutz (eds.), Die Öffentlichkeit der Vernunft und die Vernunft der Öffentlichkeit (Frankfurt/M: Suhrkamp, 2001), 539-568, pp. 541. 8. Brunkhorst, Hauke, Solidarity. From Civic Friendship to a Global Legal Community, Cambridge (MA): MIT Press, 2005). 
amount to exactly the opposite of rules of law that are more binding: a subtle dejuridification and, therewith, conflicts. Here also, three aspects can be found.

Deformalization. The expansion of the law to content-undetermined and thereby deformalized private law spurs its arbitrary interpretation and political instrumentalization. ${ }^{9}$ Its drivers are privatization processes in the domains of health, education, media, energy, security and the military, which lead to an 'unlimited self-empowerment' of the already powerful economic actors. ${ }^{10}$

Missing separation of powers in a multi-level system. This refers to the question how vertical legitimacy and control of the executive and judicial branches by the citizens can be guaranteed in a multi-plural system. ${ }^{11}$ Numerous states worldwide succeed only with difficulty in establishing and maintaining a rule of law operating to some degree authoritatively and in a way that ensures peace. The internal rule of law, however, is an essential presupposition for the steering function and bindingness of. Contrary to the idea that in a 'system of global governance', there exists a sovereignty partition between cross-linked law-making structures and implementation structures, reference is frequently made to the danger that the separation of powers limiting authority in a multilevel system can no longer be sustained if a clear-cut attribution of responsibility is not possible. The functionally differentiated systems of law emphasize the decentralization of power. As a result, a momentum of its own develops that is difficult to control and completely exacerbated by the fencing in of the executive and the independence of the judicial.

Exclusion. However, de-juridification does not exclusively proceed in a lawimmanent manner, but is rather decisively bolstered by what Hauke Brunkhorst, following and updating a term coined by Jürgen Habermas, characterizes as 'colonization of the law through power and money'. ${ }^{12}$ Political power and the market enter into an alliance that, without being based on a legal acquisition of power, cuts across the functional differentiation between right and wrong, government and opposition, haves and have-nots. ${ }^{13}$ The exclusion of a great part of the global population from access to money, knowledge, power, and judicial outlets for grievances bears witness to the fact that the differences between exclusion and inclusion have become a determining measure for the description of juridification and de-juridification. These differences also raise the question how the completely excluded, those who cannot dispose of their labour power, and hence cannot even count on the reciprocal dependence of labor and capital, can be included in the system of law.

\subsection{De-politicization.}

Lastly, questions of legitimacy are raised that have to do with the fact that the role of politics has changed in international relations. This can be accounted for

9. Koskenniemi (2004).

10. Maus, Ingeborg, "Vom Nationalstaat zum Globalstaat oder: Der Nieder $\neg$ gang der Demokratie“, in: Lutz-Bachmann, Matthias / Bohman, James (eds.), Weltstaat oder Staatenwelt?, Frankfurt/M.: Suhrkamp, 2002), 276-293, p. 255.

11. Maus (2002), Möllers, Christoph (2005), Gewaltengliederung (Tübingen: Mohr Siebeck, 2005).

12. Brunkhorst (2005), p. 166.

13. Ibid. 


\section{THE AMBIVALENCE OF JURIDIFICATION. ON LEGITIMATE GOVERNANCE IN THE INTERNATIONAL CONTEXT}

through at least three tendencies towards de-politicization.

The state between complete authority and loss of authority. Political matters were for a long time societal conflicts whereby not only those who demanded the observance of 'liberal freedoms' counted. Ever since the canon was expanded to allocation of resources, equal opportunities for access to societal institutions, and protection of minorities, many societal conflicts revolve around these issues. All problems connected therewith seemed manageable through human action. This distinguished politics from natural catastrophes, which befall humans and to which they surrender without bearing responsibility for their occurrence. At present, there is a disjunction between the expectations towards politics and its real possibilities of intervention: politics is offered complete authority, but its alleged main actor, the state, has long surrendered powers (for instance, national control of capital flows, reduction of trade barriers) to international private actors, international organizations, and international government organizations, in order to confront domestic problems such as inflation and excessive debt. ${ }^{14}$ One consequence is that an interventionist state has been transformed into a moderate state that defends the public interest in international negotiations against private actors. ${ }^{15}$

Privatization. In addition, politics withdraws from the public sphere and becomes an issue for commissions, think tanks, lobbying groups, and NGOs that are not transparent and make far-ranging decisions behind closed doors. Protection of the private interests of the citizens used to be central tenet of a liberal understanding of politics, whereas international politics increasingly moves away from this and becomes itself private. The already addressed privatization of whole domains of policies (health, senior care, energy, public transportation, etc.) deprives politics of significant possibilities of action. In addition, the transparency missing in decision-making processes complicates even further accountability for undesired consequences, the effects of which citizens must bear in the end.

Loss of power through self-actualization of politics. There existed initially a relation between the steering subject politics and the steering object society. Now this relation has drifted apart and revealed a paradox: politics has been loosened from its anchor in a national society in order to gain power vis-à-vis a globally operating economy. ${ }^{16}$ Without the connection to morality, law, and religion, to territorial borders and civic solidarity, politics self-actualizes in order to retain power, and thereby risks to lose it at the same time. Political representatives place decision-making authority in the hands of international organizations and other actors, who, following the logic proper to institutions, permanently obey only their own particular requirements. In this manner, politics obstructs precisely the steering capacities it seeks to exercise.

\footnotetext{
14. Mayntz, Renate/Scharpf, Fritz, “Politische Steuerung - Heute?”, 2005, at: http://www.mpifg.de/pu/workpap/wpo51/wpo5-1.html (last access on 1.9.2007).

15. Zumbansen, Peer, "The Conundrum of Corporate Social Responsibility: Reflections on the Changing Nature of Forms and States”, in: Miller, Russell / Bratspies, Rebecca (eds.), Transboundary Harms: Lessons from the Trail Smelter Arbitration, Cambridge (UK: Cambridge University Press, 2006), 240-253.

16. Brunkhorst (2005), p. 119.
} 
This sketch of the implications inherent in juridification already prevents one from concluding that demands for the legitimacy of governing processes should be reduced. Rather, a conception of legitimacy must reflect these 'dysfunctionalities'. How would an adequate notion of legitimate governance look like?

\section{Democratic Governance}

In what follows I will argue that the conception of legitimacy that I call 'democratic governance' is best prepared to deal with these problems, on the normative as well as the empirical level. I define 'democratic governance' as multilevel politics based on a system of institutions that are just, linked to one another, and accountable to one another and to those involved. ${ }^{17}$ By "institution", I do not refer to organizations such as the UN or the WTO, but rather to the rules of the game that coordinate our coexistence, even within organizations. This comprises norms, regulations, conventions and laws that already possess validity or will in the future be of significance for a specific community of law, be it national, regional or global. ${ }^{18}$ What is of particular interest here is the legitimacy of legally constituted institutions.

The ambivalent process of juridification, as I have laid out above, accelerates the exclusion of many from the political, and also the de-juridification and depoliticization of international politics. However, juridification can also be the motor for democratization and work as a brake on unhindered and growing administrative and executive power. For 'democratic governance', the legitimacy criteria for the assessment of this dichotomous process are supplied by the normative integration of the global society. These criteria claim to be already fixed components of normative socialization, and thereby to be able to count themselves as the outcome of a deliberative practice. Surely, an ideal is reflected in these criteria. Yet the present relations of power are reflected in the formulation of 'democratic governance' and it is clear that functional differentiation penetrates and transforms the socialization process. From the perspective of the global society the described 'dysfunctionalities' therefore arise. At the same time, however, this differentiation makes use of the 'porosity' of heterarchical, systematic integration and adds to the institutional points of intersection between global society and global system.

Global institutions, according to the thesis, are legitimate when there are good grounds for recognizing the authority of a rule of law or a system of laws. From a normative perspective this means that laws should justly regulate our coexistence in a determinate domain. From an empirical point of view these regulations are legitimate when it is not only asserted that they would be valid, but when they also actually obtain a widespread acceptance and it could be stated that they hold for most of us.

This still very vague definition of the legitimacy of global institutions needs to be made more concrete. More precisely put, global institutions are legitimate when they satisfy at least three demands, which I will discuss in more detail:

17. "Democratic governance" is linked to a 'global domestic politics without global government' (Habermas). It sets its sights on the future.

18. Pogge, Thomas, World Poverty and Human Rights, (Cambridge (UK): Polity Press, 2002), p. 170. 


\section{THE AMBIVALENCE OF JURIDIFICATION. ON LEGITIMATE GOVERNANCE IN THE INTERNATIONAL CONTEXT}

first, they should be the result of a deliberative practice that attempts to close the gap between being affected by and setting rules (1); second, the formulation of 'democratic governance' is directed towards the anchoring of democratic elements that counteract de-juridification (2); and third, a rule-setting that does not contribute to de-politicization remains dependent on active public spheres and on the sensibility of rule-setting instances vis-à-vis the 'input' from the different public forums (3). Finally, the question comes up how realistic the actualization of legitimate forms of governance is. I will briefly show that already now global actors are subject to an increased pressure for justification, created through an emerging institutional context and requiring the realization of legitimate governance (4). Let us turn to the deliberative practices first.

\subsection{Deliberative Practices}

Deliberative practices, which we find in international bargaining systems, and also in the communication structures of the European Commission, yield arguments and grounds with which those involved react to the public pressure for justification. According to a frequently applied definition, political deliberation is a practice of legitimizing the issuing of legal regulations, which depends on public discussion and reason-giving among equal citizens. ${ }^{19}$ This definition thereby distinguishes itself from the conception repeatedly encountered lately in political science according to which deliberation has become the measure for successful international relations and even the foundation of diplomatic negotiations. ${ }^{20}$ The latter conception of deliberation ignores aspects that are an important element of the politically deliberative practice and of the practice of argumentation: next to public deliberation, this encompasses the same opportunities for any individual to have access to these deliberations without being subject to an internal or external restraint, and includes the regulated exchange of information in a reason-giving process. ${ }^{21}$ Under these alleged 'ideal' conditions the participants achieve a grounded 'hypothetical agreement'. The real political process, according to a general objection against deliberative practices in international politics, proceeds otherwise in different regards, which makes deliberation seem relatively uninteresting as an adequate form of practice for many theorists. In addition,

19. Cohen, Joshua, "Deliberation and Democratic Legitimacy", in: Hamlin, Alan/ Pettit, Philip (eds.), The Good Polity (Oxford: Blackwell, 1989), 17-34, reprinted in: Bohman, James / Regh, William (eds.), Deliberative Democracy. Essays on Reason and Politics, Cambridge (MA): MIT Press, 1997) 67-93, p. 22. Here I refer to Jürgen Habermas' theory of law, which has substantially shaped the concept of 'deliberative politics'. Habermas worked out his ideas on the legitimacy of law for the democratic state of law in Between Facts and Norms (1996). Later works, dealing with the legitimacy of international law, are more cautious in terms of normative presuppositions. In "The Postnational Constellation and the Future of Democracy" (in: The Postnational Constellation. Political Essays, Cambridge (MA): MIT Press, 2001), 58-112, especially pp. 109-111), Habermas proposes two criteria as a minimum that should be fulfilled: rationality and transparency in the processes of communication and decision. For a different interpretation of deliberation, see Shapiro, Ian, "Optimal Deliberation?”, in: The Journal of Political Philosophy, 10 (2002), 196-211, who considers neither argumentation nor openness and expectation of consensus to be features of deliberation.

20. Risse, Thomas, "Global Governance and Communicative Action", in: Government and Opposition, 39 (2004), 288313; and also Müller, Harald, "Arguing, Bargaining and All That: Communicative Action, Rationalist Theory and the Logic of Appropriateness in International Relations”, in: European Journal of International Relations, 10 (2004), 395-435. 21. Cohen, Joshua (1989), pp. $17 \mathrm{ff}$. Habermas understands deliberative practice as "the core structure in a separate, constitutionally organized political system", but not as a procedure constituted for the whole of society, nor even for all state institutions (Habermas, Jürgen (1996), Between Facts and Norms. Cambridge, Mass.: 305 f.). 
the concentration on deliberation as political practice obstructs the view of other, legitimate if possible, forms of process, such as 'fair bargaining'. ${ }^{22}$ In what follows I would like to illustrate the conception of deliberation advocated here by discussing a series of objections.

A fundamental objection against deliberation is that it plays no role at all in international politics. Is it not the case that negotiations and prevailing political and economic bargaining power of the parties involved determine the content of international agreements and regulations? Recent investigations have shown that deliberative practices, understood in the previously formulated sense, rationalize the decision-making process. This happens not in all cases, but at least in some 'soft' bargaining systems, for instance in the domains of human rights and the environment. This is particularly the case when the public sphere is likewise engaged, that is, when the negotiations are transparent and representatives of NGO's have a certain influence on the outcome. ${ }^{23}$ Using the example of the implementation of human rights, Thomas Risse was able to show that in international political negotiations argumentation, deliberation and persuasion ('action oriented towards mutual understanding') become meaningful for the bargaining progress if international recognition as a legitimate bargaining partner is at stake. ${ }^{24}$ In this context he speaks of 'argumentative entrapment': even the participants that enter negotiations with a strategic intention must somehow give in to the discourse of the 'better argument' if they do not want to get caught in a contradiction. ${ }^{25}$ In this manner, reasons are produced that can be brought up as justification vis-à-vis the parties involved-be they constituents, governments, employers or NGOs. ${ }^{26}$

An additional objection frequently raised is that deliberative processes are less efficient than pure bargaining practices. ${ }^{27}$ Does deliberative legitimacy undercut the capability of political systems for action? This objection is raised with reference to the necessity of majority voting, which, however, is 'foreign' to deliberation. According to this objection, the majority principle contradicts the

22. I am thankful to Andrew Arato and Jean Cohen for this indication.

23. Nanz, Patrizia/Steffek, Jens, "Deliberation and Democracy in Global Governance", in: Toyer, Sophie / MartimortAsso, Bénoit (eds.): Participation for Sustainability in Trade (London: Ashgate, 2007), 61-72.

24. As was mentioned earlier, Risse's concept of deliberation is normatively undemanding; however, his work on the observance of human rights norms shows that in many areas a discerning concept of deliberation can already be found.

25. Risse, Thomas, “'Let’s Argue!': Communicative Action in World Politics”, in: International Organization, 54 (2000), $1-39$.

26. Habermas, Jürgen, “Kommunikative Rationalität und grenzüberschreitende Politik: eine Replik“, in: Niesen, Peter / Herborth, Benjamin (eds.), Anarchie der kommunikativen Freiheit.Jürgen Habermas und die Theorie der internationalen Politik (Frankfurt/M.: Suhrkamp, 2007), 406-460, p. 436. Justification can be understood in a very narrow sense as 'internal justification (accountability)': agents or political representatives have the corresponding duty to answer to their employers or constituents (Keohane, Robert, "Global Governance and Democratic Accountability”, in: Held, David/ KoenigArchibugi, Mathias (eds.), Taming Globalization (Cambridge, Polity Press, 2003), 130-160). Nonetheless, in a globalized economy with its undesired consequences for many this seems insufficient. 'External justification (accountability)' involves a more broadly conceived openness. According to this, all those exposed to an outcome an institution produces, e.g., environmental catastrophes, unhealthy products, or low wages, are entitled to a justification; institutions that either do not prevent such harms or even foster them are liable to a similar duty of justification. The concept of accountability assessed here springs from reciprocal accountability (Forst, Rainer, "The Right to Justification. Toward a Constructivist Conception of Human Rights", in: Constellations 6 (1999), 35-60).

27. Scharpf, Fritz, Governing in Europe. Effective and Democratic? (Oxford: Oxford University Press, 1999). 


\section{THE AMBIVALENCE OF JURIDIFICATION. ON LEGITIMATE GOVERNANCE IN THE INTERNATIONAL CONTEXT}

conception that autonomous citizens reach consensus through understanding. The technical element of an aggregate of voices does not admit that one can hypothetically decide against the will of the majority on the basis of morally persuasive opinions. ${ }^{28}$ Yet, it is not such an easy matter. In what follows I will concentrate on a central point.

It is misleading to assume that a post-deliberative majority decision is completely insensitive to the quality of arguments and thereby to their rationality. This would mean to deny that the deliberative process has any influence on the aggregate of voices and that aggregation could proceed in a democracy in principle independently of any previous argumentation. This is a quite shortsighted assumption. Namely, what is 'extracted' through deliberation are precisely those arguments that persuade a majority and impose on a minority the task of coming up with a better argument. ${ }^{29}$ The majority principle determines which arguments experience more approval at time X. One could say it is a type of indicator of the present state of the argumentation. If the majority principle only served to aggregate voices, without connecting back to a deliberative practice, one could even do without the institutional anchoring of processes of formation of opinions and wills, and simply carry out periodical 'opinion polls'. However, such a procedure clearly contradicts our conception of democracy by which minorities should again and again have the chance to challenge the status quo.

Deliberation is accused of inefficiency also for a second reason. It allegedly concentrates on the input- and so-called through-put legitimacy, the legitimacy of the practice, but does not aim at output-legitimacy. For this reason alone the applicability of the outcome and its consequences play a rather subordinate role. In a well-cited contribution and with a view towards the European Union, Fritz Scharpf remarked that missing input-legitimacy can and should be replaced by output-legitimacy-a recommendation also taken up for global governance. Since one can speak neither of a European demos nor of a European identity or even solidarity, although according to Scharpf there is considerable need for regulation, it would do the EU well to concentrate on its problem-solving capacities. ${ }^{30}$ Deliberation theory, however, does not concern the critique of the neglect of the output-legitimacy. An advantage of this formulation is, namely, that the process of argumentation is always already directed towards problemsolving. The possible negative consequences and side effects of a regulation are injected into the deliberative process as arguments and can be invoked against the adoption of a controversial regulation. In addition, a problem-solving strategy is more successful the more thoroughly integrated the parties concerned are into the rule-setting process. In the end they are the ones who must deal with the results in different societal domains. Success would come sooner if they were involved in the rule-setting process and correspondingly adopted the result. According to

28. Gosepath, Stefan, “Democracy out of Reason? Comment on Rainer Forst's ‘The Rule of Reason”, in: Ratio Juris, 14 (2001), 379-390.

29. Lafont, Cristina, "Is the Ideal of a Deliberative Democracy Coherent?”, in: Besson, Samantha/Martí, Jose Luis (eds.), Deliberative Democracy and Its Discontents (London: Ashgate, 2006), 3-26.

30. Scharpf (1999). 
studies, the problem of insufficient compliance with norms does not appear more serious than at a domestic level. ${ }^{31}$ Thus, the effectiveness of global governance is directly connected to the quality of the decision-making process.

Finally, the possibility of establishing congruence between subjection to and authoring of rules is called into question. ${ }^{32}$ Who should be included? According to which measure will it be decided who shall participate in which rule-setting process? A principle that can offer an answer to this is the so-called 'principle of affectedness', which states that all those who are affected by the outcome of a regulation should also be involved in its development. Defined in this general manner, the principle is still very vague. The question regarding how to measure affectedness needs to be made more concrete.

The determining feature is the effect on vital interests and human needs. ${ }^{33}$ What is at stake here are not the effects of decisions, for instance, of a neighbor that, by developing her property, reduces the amount of light in my apartment, or of a management that decides to raise the price of coffee - although both naturally have effects on my life. It is rather institutions - norms, regulations, rights, conventions - standing in the foreground that are valid for a determinate community, be it national, regional, or global. ${ }^{34}$ What is meant by 'affectedness' here is to what degree access to essential resources through institutions is prevented or facilitated. For a more detailed determination of 'affectedness', one should distinguish between fundamental, expanded and marginal interests.

Fundamental interests are affected when existing institutions approve of or even encourage lack of command over one's own life and its physical integrity, or when its development is threatened or sharply curtailed. Among these fundamental interests, next to subsistence, health care, and education, one also finds the exercise of cultural practices, for instance the practice of faith, and a political participation that enables making these interests publicly thematic. Expanded interests are affected when existing institutions approve of or even encourage needs exceeding elementary needs. These refer to equal opportunities for participation in public, economic, and private life, and the fulfillment of life projects made possible through them, which concern public life, vocation, and family. Finally, marginal interests are affected when that requires challenging aesthetic or material presuppositions relating to 'lifestyle'.

For the identification of those who should be involved in the law-making

31. Zürn, Michael, "Introduction: Law and Compliance at Different Levels”, in: Zürn, Michael/Joerges, Christian (eds.), Law and Governance in Postnational Europe. Compliance Beyond the Nation-State, (Cambridge: Cambridge University Press, 2005), 3-40, pp. 26 ff.; Risse (2004).

32. Due to reasons of space, I cannot address a further problem, namely, that the principle of affectedness only functions on a small scale. For this critique, see Goodin, Robert, "Democratic Deliberation Within", in: Philosophy and Public Affairs, 29 (2000), 81-109. Parkinson, John, "Legitimacy Problems in Deliberative Democracy", in: Political Studies, 51 (2003), 180-196; and Dryzek, John, "Legitimacy and Economy in Deliberative Democracy", in: Political Theory 29 (2001), 651-669, among others, reject this criticism.

33. Held, David, "Democratic Accountability and Political Effectiveness", in: Government and Opposition, 39 (2004), 364-391, pp. 373 ff.; Kreide, Regina, Globale Politik und Menschenrechte. Macht und Ohnmacht eines politischen Instruments (Frankfurt/M./New York: Campus, 2008), pp. $166 \mathrm{ff}$. David Held uses the term 'significantly affected' and speaks of 'strong, moderate and weak interests'.

34. Pogge (2002), p. 170. 


\section{THE AMBIVALENCE OF JURIDIFICATION. ON LEGITIMATE GOVERNANCE IN THE INTERNATIONAL CONTEXT}

processes, only the first two aspects are relevant; only they possess the necessary potential of being general enough to expect agreement of all those concerned with making concrete the principle of affectedness. The 'principle of affectedness' is inclusive and aims at the highest possible congruence between the circle of those whose fundamental and expanded interests are subject to political rule and the circle of those who exercise this rule.

The ideal of (transnational) deliberation advocated here is only one of four aspects that characterize, democratic governance'. The related question is: "What space does democracy occupy?". The relation between deliberation and democracy is in no way free of tension. Deliberation, in contrast to democracy, aims at generalizable interests and not at individual self-interest. It requires congruence between those subject to regulation and the authors of regulation, and is not satisfied with indirect representation. In a deliberative practice, what counts is the argument and not the amount of votes-only to mention some important points. And yet, deliberation and democracy refer to one another. Without the connection to democratic elements, deliberation remains a regulation practice that neither effectively institutionalizes the principle of congruence, nor possesses the capacity to adequately react against de-juridification and de-politicization.

\subsection{Democratic Elements}

Deliberative processes alone cannot close the legitimacy gap that emerges when international treaties, decisions, or even internationallybinding conventions are for the most part not even indirectly linked back to democratic constitutions through the states involved in the negotiations. Therefore, it requires democratic elements, that is, institutional hinges that, analogous to inner-societal organizations, adopt democratic functions in a decentralized multi-level system. ${ }^{35}$ An institutionally anchored participation of the citizens, the requirement that the executive act through legal means, and that acts of the executive can always be challenged in independent courts are only some proposals I will more closely address in what follows.

Deliberation cannot adequately institutionally represent the interests of marginalized groups. Minority positions must also obtain actual access to negotiations and possess influence on decision-making. An expansion of the possibilities of citizens' political cooperation would prevent the law from not only becoming pluralized internally, but also from losing external sovereignty vis-àvis other systems of norms and complexes of rules (perhaps local traditions). But how could this look in political reality? The minimal normative foundation for legal unity should also prospectively embody the United Nations charter. It could possess constitutional status, in contrast to the lex mercatoria, since it is based on international agreements and its basic elements are reflected in domestic constitutions that have been at least partially achieved through referenda. ${ }^{36}$ The

35. Forst, Rainer, "Dialektik der Moral. Grundlagen einer Diskurstheorie transnationaler Gerechtigkeit", in: Forst, Rainer, Das Recht auf Rechtfertigung (Frankfurt/M: Suhrkamp, 2007), 343-357 (transl. into English by Flynn, Jeff: The Right to Justification, New York: Columbia University Press, in preparation) also argues for inner-societal equivalents in the form of democratic elements.

36. Habermas (2007), p. 450. 
long discussed reform to the United Nations should aim at including the General Assembly 'in deliberative ways in the decision-making of the Security Council' and also making it an organ that represents the world citizens. This could perhaps occur by long-term transformation into a world parliament consisting of delegates from democratically elected parliaments (and a chamber of state representatives). Even in the World Security Council a fundamental principle of the Charter must be made procedural, namely, that of the sovereign equality of all member states. Only then would the participation of all states in decision-making be assured, independent of their economic and political power.

Beneath the level of world organizations one can already recognize indications of the constitutionalization of democratic participation. By now, political affiliation has been detached from the general state citizenship that encompasses all rights. Regional and international norms ensure entitlements for the individual beyond nation state borders (above all, at the EU level), whereas the political activities of the citizens are positioned at local, regional and international levels. Decentralized, deliberative forums for issues such as human rights, environment, health, retirement plans, and energy are precursors to an institutional participation in brain trusts and decision-making organs. The EU in particular regards itself as open to the demand for a democratization of its governance and attempts to honor it, even in the failed constitutional EU draft.

What deliberation alone lacks, as was already mentioned, are the legal instruments to achieve a transnational institutionalized control of the executive and administration. For this, institutional efforts are required to bind international administrative organizations (for example, WTO or NATO) to nation state, democratically achieved decisions. Only by virtue of this is administrative power subject to the democratic will of the citizens. Legal obligations are a normative pillar of nation state democracies, but are not easy to establish at a transnational level. The fencing in of the executive by classical international organizations such as NATO still functions transnationally to some extent since its representatives must abandon accountability to the constituency 'at home'. ${ }^{37}$ Even international organizations such as the WTO, the World Bank and the International Monetary Fund, are aware of their external responsibilities regarding justification and have become sensible vis-á-vis those affected by their decisions. Studies show that precisely these organizations have opened themselves up to participation of NGOs, and this has amounted to the formalization of relations between international organizations and NGOs. ${ }^{38}$ For international organizations, this presents a possibility for tapping into one of the state-independent sources of legitimacy. This indeed weakens the connection back to the domestic constituency, but simultaneously strengthens the position of those citizens that do not come from democratic industrialized states and can only count on support from NGOs.

Foreseeably, this may account for substantial differences regarding the openness

37. Brunkhorst, Hauke, “Zwischen transnationaler Klassenherrschaft und egalitärer Konstitutionalisierung”, in: Niesen, Peter/Herborth , Benjamin (eds.), Anarchie der kommunikativen Freiheit. Jürgen Habermas und die Theorie der internationalen Politik (Frankfurt/M.: Suhrkamp, 2007), 321-349, p. 337.

38. Nanz/Steffek (2007). 


\section{THE AMBIVALENCE OF JURIDIFICATION. ON LEGITIMATE GOVERNANCE IN THE INTERNATIONAL CONTEXT}

of the differentinternationalorganizations vis-à-vis civil societygroups. Whereas in the project-oriented international organizations specializing in humanitarian aid, economic cooperation, human rights work, or the environment (Forest Stuartship Council) there is intensive cooperation, the large economic organizations (WTO) open up only moderately (NGOs have consultation rights there), and the financial organizations (IMF) next to nothing at all. This reluctance of the World Bank and the IMF is explained by the danger of counter-productive financial speculations that may increase if too many people have too much knowledge about the ongoing financial projects. ${ }^{39}$ Reader might not know what "counter-productive speculation"is. The fencing in of administrative instances is also difficult because in addition to the national parliaments there are other transnational law-giving instances. Overriding national parliaments, an arbitration mechanism added to the organization becomes a legislative organ. ${ }^{40}$

Hence, to conclude, needed is also a transnational expansion of the existing legal guarantees of rights through which the equality of the bargaining partners can be achieved independently of economic and political bargaining power. Independent arbitration is an important step on the way to a transnational legal guarantee of rights and, next to the signs of a self-developing democratic legitimation, a further aspect of the constitutionalization of international relations. Since the nineties organs similar to courts have been created for a range of international procedures, which provide a binding interpretation of international norms of law and an at least approximate equality of parties. An investigation by Bernhard Zangl shows that the juridification of international procedures for dispute settlements has led to an increased readiness of member states of the OECD to follow these procedures. ${ }^{41}$ The increase of juridified dispute settlement procedures is of enormous importance for the equal treatment of parties of varied power when laws have been breached. However, it is also beyond question that the organs for settling disputes judge independently, above all from a political point of view, only when the judges belong to a permanent judicial panel and do not receive their salary from 'their' state or from private actors. ${ }^{42}$

\subsection{Public Spheres}

The inclusion of marginalized, relatively powerless, economically deprived population groups affected by transnational decisions depends decisively on the pressure of public spheres on international organizations. The significance of public spheres has been subject to a considerable change in the last thirty years. In the seventies and eighties 'civil society' was still a political space for the autonomous self-organization of the citizens, who defied the military regimes in Latin America and Eastern Europe. ${ }^{43}$ In the nineties an increased critique

\footnotetext{
39. Nanz/Steffek (2007).

40. Brunkhorst (2007), p. 337.

41. Zangl, Bernhard, Internationalisierung der Rechtsstaatlichkeit (Frankfurt am Main/New York: Campus, 2006), pp. $237 \mathrm{ff}$.

42. Ibid, p. 51.

43. For Latin America and the international networking of its civil society organisations, see Keck, Margaret E./Sikkink, Kathryn, Activists Beyond Borders (Ithaca/London: Cornell University Press, 1998); for a theory of civil society and Eastern Europe, see Cohen, Jean L./Arato, Andrew, Civil Society and Political Theory (Cambridge (MA): MIT Press, 1994).
} 
emerged against the 'tamed' social movements that appeared in the form of transnationally operating NGO's that act very professionalized but by doing so suited everybody, from the activists to the trans-national entities and the international government organizations. ${ }^{44}$ Yet the NGOs embody the promise of externalizing the 'inner': protests, ideas and activities become global. ${ }^{45}$ For this reason they are the opposite of the terror that internalizes the 'external' above all by evoking angst among the population by means of repression, violence and arbitrariness, and by wanting to strangle any civic commitment. Despite the danger of global terror, social movements and NGOs that lobby international organizations have not let themselves be pushed back. ${ }^{46}$ The gap between professionally working NGOs and social movements, however, is often not as large as feared. For, NGOs rely on weak or informal public spheres, those public spheres that can prosper under the shadow of the fundamental right to freedom, but without having decision-making authority at their disposal. ${ }^{47}$ Their strength lies in being able to oppose something to the continuously threatening encroachments through the system-instrumental domain of organization (administrative control). However, faith in the vigilant public sphere, coupled with the supposition that bargaining in international organizations proceeds through deliberation, occasionally obstruct the view of the institutional necessity of fencing in the unleashed administrative and private law systems in order to protect nation state sovereignty.

Hence, informal public spheres must be completed through formal ones that are assessed not only by the practical implementation of elections and referenda; they also establish hard law, that is, enforceable law and possibilities of action at all levels of interpretation, concretization and implementation of the law. They make possible a structural coupling between statements, political actions, and civil disobedience, on the one side, and test cases and verdicts, which can effectively enforce civil and international law norms, on the other. Examples of this can be found in international labor laws, where companies in Indonesia have been accused courts in California of violating legal labor standards. A negative example in which the informal public sphere actually remains weak are the street children in Brazil, where, despite spectacular international protests by NGOs, no proper criminal proceeding following the rule of law has taken place. ${ }^{48}$

\subsection{Institutional Context}

These empirically substantiated achievements show that we do not have to accept the 'powerlessness of the ought'. It must be added that present developments in the domain of transnational governance, as well as in international law, can

44. Chandhoke, Neera, The Conceits of Civil Society (Oxford: Oxford University Press, 2003), pp. 90-137. 45. Kaldor, Mary, "The Idea of Global Civil Society", in: International Affairs, 79 (2003), 583-595, p. 591.

46. For a good overview of different activities, publications and counter-positions, see Broad, Robin, Global Backlash. Citizen Initiatives for a Just World Economy (Lanham: Rowman \& Littlefield, 2002); see also Keane, John, Global Civil Society? (Cambridge (UK): Cambridge University Press, 2003).

47. Fraser, Nancy, "Rethinking the Public Sphere: A Contribution to the Critique of Actually Existing Democracy", in: Fraser, Nancy, Justice Interruptus. Critical Reflections on the "Postsocialist" Condition, London: Routledge 1996, 69-98; Brunkhorst, (2005).

48. Brunkhorst, Hauke, "Globalizing Democracy Without a State: Weak Public, Strong Public, Global Constitutionalism", in: Millennium 31 (2002), 675-690. 


\section{THE AMBIVALENCE OF JURIDIFICATION. ON LEGITIMATE GOVERNANCE IN THE INTERNATIONAL CONTEXT}

be understood as institutional context that, insofar as it generates pressure for justification and control, advances the implementation of legitimate processes of juridification. To name only one example: by now a juridical network has developed through the implementation of human rights obligations for collective, private actors. Among these are formulations of international liability for private actors, indictments regarding complicity with these same actors when grave human rights violations are at stake, even ILO agreements and private-public partnerships, such as the Global Compact. ${ }^{49}$ They present empirical structural inducements that make it difficult for global actors to reject deliberative rulesetting processes and to prevent other actors from abiding by international law agreements (for instance those pressed by the International Labour Organisation - ILO) and from being subject to independent jurisdictions. The limits of the 'disembedding' of the law and even of the market from political contexts lay in deliberative action.

\section{Conclusion}

Because of the juridification of international relations transnational governance seldom runs along informal paths, and is rather strengthened in legally formalized, decentralized paths. However, according to the argumentation, this development is highly ambiguous. On the one hand, it causes subjection to rules and authoring of rules to drift apart from one another; it accelerates de-juridification through deformalized law and undermines the bindingness of nation state civil law regimes; and it advances a de-politicization of political decision-making processes. On the other hand, juridification recovers the potential for taming precisely these 'dysfunctionalities'. Law then becomes the engine for the development of legitimate global forms of government.

Against this background I have argued that transnational governance forms are legitimate when, firstly, a deliberative practice closes the gap between being affected by and setting rules; second, when de-juridification is counter-acted by anchoring democratic elements; and, third, when those involved can trust in the sensitivity of the rule-setting instances to the 'input' from different public forums. A democratic transnational government binds deliberation and democratic elements together: without democratic elements it amounts to the exclusion of marginalized minorities, whose position is perpetuated by informal mechanisms through which majority power is exercised. Without deliberation, however, the practice becomes trivial; it does not do justice to the complexity of the problems to be solved, and it becomes less important for those involved, for whom the results are merely decreed. ${ }^{50}$

49. Kupers, Andrew, "Redistributing Responsibilities - the UN Global Compact with Corporations", in: Follesdal, Andreas/ Pogge, Thomas (eds.), Real World Justice, Dordrecht: Springer, 2005, 359-380; Kreide, Regina, "The Obligations of Transnational Corporations in the Global Context. Normative Grounds, Real Policy, and Legitimate Governance, in: Èthique et Èconomique / Ethics and Economics, vol. 4/2 (2007), 160-179.

50. Brunkhorst (2007), p. 333 . 
The potential of a critique of the existing legal relationships feeds on the normative integration of the global society. Without societal resistance against the colonialization of the global society through juridification, functional differentiation proceeds unhindered. In the end, only the unbridled force of the public spheres and the domesticating power of legitimate hard law can call a halt to this process.

Regina Kreide

Johann Wolfgang Goethe-Universität,

the global justicenetwork

Frankfurt am Main 